\title{
Evaluation of the Quality and Reliability of Youtube Videos on Neurological Symptoms of COVID-19
}

\author{
Özgül Ocak ${ }^{1}$ iD , Alper Şener ${ }^{2}$ (iD
}

'Department of Neurology, Faculty of Medicine, Çanakkale Onsekiz Mart University, Çanakkale, Turkey

${ }^{2}$ Department of Infectious Disease, Faculty of Medicine, İzmir Katip Çelebi University, İzmir, Turkey

Özgül OCAK

Alper ŞENER

Correspondence: Özgül 0cak Department of Neurology, Faculty of Medicine, Çanakkale Onsekiz Mart University, Çanakkale, Turkey

Phone: +905058320631

E-mail:dr_ozgul@hotmail.com

$\begin{array}{ll}\text { Received } & : 16 \text { July } 2021 \\ \text { Accepted } & : 140 \text { ctober } 2021\end{array}$

\section{ABSTRACT}

Purpose: The objective of this study was to identify key features of the videos related to neurological symptoms of COVID-19 published on YouTube and evaluate the quality and reliability of them.

Methods: YouTube searches was performed using keywords "COVID -19 Neurological Symptoms" and the first 50 YouTube videos with the highest number of views were evaluated by one neurologist and one infectious disease specialist with DISCERN and JAWA scoring systems.

Results: Videos uploaded by health channels (50\%), news channels (26\%), physicians (22\%), or patients (2\%). The mean Video Power Index value was 95.51. The mean DISCERN score was $46.59 \pm 10.90$ (average) and the mean JAMA score was $2.87 \pm 0.65$. Health Channel mean JAMA and DISCERN scores were higher than News Channel scores. DISCERN or JAMA scores did not correlate with view counts, view rate, comment counts, like counts, or dislike counts.

Conclusion: Proper use of Youtube as a source for reaching information, can play a role in managing the COVID-19 outbreak. Lack of control on video sources reduces validity of information. With the increase of the publication of videos by neurologists, the spread of false information can be minimized.

Keywords: COVID-19, neurologic symptoms, instructional film and video

\section{COVID-19 Nörolojik Belirtileri Üzerine Youtube Videolarının Kalite ve Güvenilirliği}

ÖZET

Amaç: Bu çalışmanın amacı, COVID-19'un nörolojik semptomlarılla ilgili YouTube'da yer alan videoların temel özelliklerini belirlemek ve geçerlilik ve kalitelerini incelemektir.

Yöntemler: YouTube üzerinde "COVID -19 Nörolojik Belirtiler" anahtar kelimeleri kullanılarak arama gerçekleştirildi ve belirlenen en yüksek görüntüleme sayılarına sahip 50 video bir nörolog ve bir enfeksiyon hastalıkları uzmanı tarafından DISCERN ve JAWA puanlaması ile değerlendirildi.

Bulgular: Videolar sağık kanalları (\%50), haber kanalları (\%26), doktorlar (\%22) veya hastalar (\%2) tarafindan

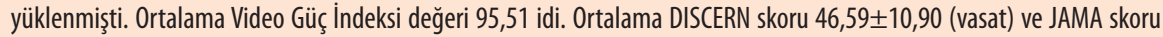
$2,87 \pm 0,65$ idi. Sağlık kanalı ortalama DISCERN ve JAMA puanları haber kanalı puanlarından anlamlı daha yüksekti. DISCERN veya JAMA puanları ile görüntüleme sayıları, görüntüleme oranları, yorum sayıları, beğenme sayıları veya beğenmeme sayıları arasında istatistiksel olarak anlamlı bir ilişki yoktu.

Sonuç: Youtube'un bilgi kaynağı olarak doğru kullanımı, COVID-19 salgınının başarılı bir şekilde yönetilmesinde rol oynayabilir. Video kaynakları üzerinde kontrol bulunmaması bilgi geçerliğini düşürmektedir. Nörologlar tarafından videoların yayınlanmass ile yanıış bilgi yayılımı en aza indirilebilir.

Anahtar kelimeler: COVID-19, nörolojik semptomlar, eğitici film ve videolar 
$\mathbf{T}$ he internet, which is used as the fastest and most widespread source of information, has enabled the public to access many health related information (1). Internet is used by more than 70 percent of the adult population as a resource on health-related issues (2). Youtube is one of the most important social media sites, is used by $95 \%$ of those who use the internet and has over 2 billion monthly active users (3).

Even if patients can easily access information about their illnesses, they cannot always access quality and accurate information through the internet (4). People have been shown that use the internet to get information about the diseases and medical treatments, and to learn about other people's health experiences (4-5).

It has been shown in previous studies that Youtube provided misleading information as well as useful information in Zika, H1N1 and Ebola outbreaks. It was stated in these studies that $23 \%$ to $26.3 \%$ gave misleading information (6).

Covid-19 is one of the most serious epidemics in history (7). The respiratory system was in the foreground and most frequently reported clinical symptoms include fever, shortness of breath and cough. Many neurological findings including headache, hyposmia / anosmia, nausea, vomiting, myalgia, dizziness, Guillain-Barré syndrome (GBS), seizures, encephalitis and impaired consciousness (meningoencephalitis and encephalopathy) can be observed during COVID-19 disease (8-9).

The objective of this study was to identify key features of the videos related to neurological symptoms of COVID-19 published on YouTube and evaluate the quality and reliability of them.

\section{MATERIAL AND METHODS}

A screening was performed by "COVID - 19 Neurological Symptoms" in the YouTube search bar with "view count" filter option. Search results sorted for the most viewed videos. The top 50 videos with the highest views on YouTube were evaluated by a neurologist and an infectious disease specialist. Two reviewers watched 50 videos included and analyzed them all.

Non-audio, non-visual, non-English videos, and videos less than one minute and over an hour, advertising and animation videos were not included in the study. Only the first video from two or more repeated videos included.
The titles, the number of views, the video duration, the number of likes, dislikes, and the number of comments were recorded.

YouTube videos are divided into subgroups according to video source as health channels, news channels, physicians, and patients. The Video Power Index (VPI), which determines the popularity of videos, is calculated with the following formula (10).

VPI $=[($ like count/dislike count + like count $) \times 100)]$

\section{Quality Assessment}

Selected Youtube videos were watched by a neurologist and an infectious disease specialists simultaneously. The videos were evaluated according to DISCERN (Quality Criteria for Consumer Health Information) (Table1) (11) and JAMA (Journal of the American Medical Association) scoring systems (Table 2) (12). Scores were recorded by the observers separately and the mean scores were calculated (13).

The DISCERN scoring system consists of 16 questions and each question scores between 1 and 5 points results in a total score ranging between 16 and 75 . There are three separate sections, treatment information (7 questions), reliability of the information (8 questions), and general quality of the information (1 question) (13-14). A higher score indicated higher quality of information. Scores were classified as 'excellent' between 75 and 63 points, as 'good' between 62 and 51 points, as 'average' between 50 and 39 points, as 'poor' between 38 and 28 points, and as 'very poor' below 28 points. (11).

The JAMA scoring system is one of the leading tools used to evaluate the medical information obtained from websites. It includes 4 criteria (Currency, Attribution, Disclosure, Authorship) of 1 point each with a total possible score of 4 points which indicates the highest quality (12).

After the data were digitalized and corrected, the ordinal data were presented with frequency and percent, the categorical data were presented with mean and standard deviation for descriptive information. Analyzes were carried out using Chi-square test, Kruskal Wallis test, Spearman correlation test in accordance with variable characteristics. Dunn test was used for the post hoc analyses of the Kruskal Wallis test. Test constants and absolute $p$ values were presented for all analyzes, $\mathrm{p}<0.05$ was accepted as the general significance limit. 
TABLE 1: DISCERN Scoring System

\begin{tabular}{|c|c|c|c|c|c|c|}
\hline Section & Questions & \multicolumn{5}{|c|}{ Scoring } \\
\hline \multirow{8}{*}{$\begin{array}{l}\text { Reliability of the } \\
\text { publication }\end{array}$} & 1. Explicit aims & Yes & \multicolumn{3}{|c|}{ Partly } & No \\
\hline & 2. Aims achieved & 1 & 2 & 3 & 4 & 5 \\
\hline & 3. Relevance to patients & 1 & 2 & 3 & 4 & 5 \\
\hline & 4. Source of information & 1 & 2 & 3 & 4 & 5 \\
\hline & 5. Currency (date) of information & 1 & 2 & 3 & 4 & 5 \\
\hline & 6. Bias and balance & 1 & 2 & 3 & 4 & 5 \\
\hline & 7. Additional sources of information & 1 & 2 & 3 & 4 & 5 \\
\hline & 8. Reference to areas of uncertainty & 1 & 2 & 3 & 4 & 5 \\
\hline \multirow{7}{*}{$\begin{array}{l}\text { Quality of information on } \\
\text { treatment choices }\end{array}$} & 9. How treatment works & 1 & 2 & 3 & 4 & 5 \\
\hline & 10. Benefits of treatment & 1 & 2 & 3 & 4 & 5 \\
\hline & 11. Risks of treatment & 1 & 2 & 3 & 4 & 5 \\
\hline & 12. No treatment options & 1 & 2 & 3 & 4 & 5 \\
\hline & 13. Quality of life & 1 & 2 & 3 & 4 & 5 \\
\hline & 14. Other treatment options & 1 & 2 & 3 & 4 & 5 \\
\hline & 15. Shared decision making & 1 & 2 & 3 & 4 & 5 \\
\hline $\begin{array}{l}\text { Overall rating of the } \\
\text { publication }\end{array}$ & $\begin{array}{l}\text { 16. Based on the answers to all of these questions, } \\
\text { rate the overall quality of the publication as a source } \\
\text { of information about treatment choices }\end{array}$ & 1 & 2 & 3 & 4 & 5 \\
\hline
\end{tabular}

\section{TABLE 2: JAMA Scoring System}

\begin{tabular}{|c|l|c|c|}
\hline \multirow{2}{*}{ Section } & & \multicolumn{2}{|c|}{ Rating } \\
\cline { 3 - 4 } & & No & \multicolumn{2}{|c|}{ Yes } \\
\hline Authorship & $\begin{array}{l}\text { Authors and contributors, their affiliations, and relevant credentials should be } \\
\text { provided }\end{array}$ & 0 \\
\hline Attribution & $\begin{array}{l}\text { References and sources for all content should be listed clearly, and all relevant } \\
\text { copyright information should be noted }\end{array}$ & 0 \\
\hline Disclosure & $\begin{array}{l}\text { Website "ownership" should be prominently and fully disclosed, as should any } \\
\text { sponsorship, advertising, underwriting, commercial funding arrangements or } \\
\text { support, or potential conflicts of interest }\end{array}$ & 0 \\
\hline Currency & Dates when content was posted and updated should be indicated & 1 \\
\hline
\end{tabular}

\section{RESULTS}

Of the 68 videos screened 50 videos (73.5\%) were included. The remaining 18 videos (26.5\%) were excluded for non-English language (8), less than 1 minute (1), over 1 hour long (8) or duplicates (1).

Of the 50 videos evaluated, source of upload were health channels for 25 (50\%), news channels for 13 (26\%), physicians for 11 (22\%), and patients for 1 (2\%) (Table 3).The mean video length was 13.46 minutes (1.43-57.59 minutes).
Fifty included videos was viewed 136,600 times in total with the mean of 2732 (104 to 39740) times. The mean view rate was 69.47 per day (1.24 to 894.00 per day). There was 16.46 (0 to 200) comments for each video. The mean number of likes was 46.54 ( 1 to 413 ), the mean number of dislikes was 1.88 (0 to 19). The mean VPI value was calculated as 95.51 (66.67 to 100). Key features of the evaluated videos are given in Table 3. 


\section{TABLE 3: Analyzed videos and their main features}

\begin{tabular}{|c|c|c|c|c|c|c|c|}
\hline $\begin{array}{l}\text { Video } \\
\text { number }\end{array}$ & Video name & $\begin{array}{c}\text { Video } \\
\text { length } \\
\text { (minutes) }\end{array}$ & $\begin{array}{l}\text { View } \\
\text { count }\end{array}$ & $\begin{array}{l}\text { Time } \\
\text { since } \\
\text { video } \\
\text { upload } \\
\text { (days) }\end{array}$ & $\begin{array}{c}\text { Comment } \\
\text { count }\end{array}$ & $\begin{array}{l}\text { Like } \\
\text { count }\end{array}$ & $\begin{array}{l}\text { Dislike } \\
\text { count }\end{array}$ \\
\hline 1 & $\begin{array}{l}\text { New Concerns Over How Coronavirus Impacts The Brain | NBC } \\
\text { Nightly News }\end{array}$ & 2.27 & 39740 & 55 & 78 & 292 & 12 \\
\hline 2 & Lesser-known symptoms of coronavirus & 2.03 & 16107 & 54 & 0 & 127 & 8 \\
\hline 3 & Coronavirus May Cause Brain Damage & 1.56 & 10185 & 58 & 200 & 355 & 19 \\
\hline 4 & COVID-19: A Global Perspective - American Academy of Neurology & 23.46 & 9792 & 78 & 11 & 74 & 4 \\
\hline 5 & Jennifer Frontera, MD: Neurologic Symptoms of COVID-19 & 7.44 & 8470 & 43 & 86 & 90 & 9 \\
\hline 6 & $\begin{array}{l}\text { NeuroBytes: What Neurologists Should Know About COVID-19- } \\
\text { American Academy of Neurology }\end{array}$ & 3.52 & 6749 & 57 & 1 & 67 & 1 \\
\hline 7 & How COVID-19 Affects The Brain & 8.24 & 5829 & 39 & 87 & 413 & 13 \\
\hline 8 & $\begin{array}{l}\text { Neurologic Complications of COVID-19: Separating Fact from } \\
\text { Fiction - American Academy of Neurology }\end{array}$ & 24.47 & 5046 & 55 & 8 & 104 & 3 \\
\hline 9 & Strange Neurological Symptoms & 5.32 & 3585 & 87 & 137 & 114 & 0 \\
\hline 10 & Woman with COVID 19 developed a rare brain condition & 2.06 & 3231 & 41 & 8 & 51 & 1 \\
\hline 11 & Covid-19Neurolnvasion:Dr. Judy Mikovits Medical Corruption & 25.00 & 3025 & 38 & 11 & 36 & 0 \\
\hline 12 & Covid-19 and encephalitis - podcast & 36.28 & 2959 & 83 & 6 & 41 & 1 \\
\hline 13 & $\begin{array}{l}\text { Mayo Clinic Q\&A podcast: Possible neurological effects of } \\
\text { COVID-19 }\end{array}$ & 13.00 & 1901 & 41 & 7 & 25 & 2 \\
\hline 14 & COVID-19 impact on the brain & 1.56 & 1757 & 50 & 1 & 24 & 4 \\
\hline 15 & $\begin{array}{l}\text { COVID-19: How the Pandemic is Impacting Neurology - An } \\
\text { Update - American Academy of Neurology }\end{array}$ & 19.00 & 1757 & 62 & 8 & 30 & 0 \\
\hline 16 & $\begin{array}{l}\text { COVID-19: Neurology on the Leading Edge: Lessons from the } \\
\text { Pandemic in Italy - AAN }\end{array}$ & 57.17 & 1554 & 30 & 1 & 33 & 0 \\
\hline 17 & COVID-19 from Neurological Perspective & 3.55 & 1339 & 75 & 5 & 30 & 1 \\
\hline 18 & COVID19: Precautions for Neurology Patients & 3.48 & 1139 & 63 & 0 & 1 & 0 \\
\hline 19 & $\begin{array}{l}\text { Neurologist talks about risk of blood clots, stroke, and heart attack } \\
\text { associated with COVID-19 }\end{array}$ & 3.53 & 1125 & 44 & 0 & 9 & 0 \\
\hline 20 & $\begin{array}{l}\text { NeuroBytes: Cerebrovascular Complications \& Management of } \\
\text { COVID-19 - American Academy of Neurology }\end{array}$ & 4.53 & 1002 & 27 & 0 & 33 & 0 \\
\hline 21 & Doctors Study the Lingering Symptoms of Covid-19 & 3.20 & 894 & 1 & 9 & 27 & 2 \\
\hline 22 & $\begin{array}{l}\text { COVID-19: What Every Practitioner Should Know - American } \\
\text { Academy of Neurology }\end{array}$ & 25.03 & 662 & 62 & 1 & 13 & 2 \\
\hline 23 & Covid-19 and Neurology & 27.06 & 603 & 58 & 2 & 11 & 1 \\
\hline 24 & Coronavirus may attack the brain and nervous system & 1.43 & 603 & 28 & 0 & 27 & 1 \\
\hline 25 & COVID-19 from Neurological Perspective -Part 2 & 6.46 & 566 & 66 & 0 & 20 & 0 \\
\hline 26 & $\begin{array}{l}\text { Neurologist explains COVID-19 and Stroke, Encephalitis, Guillain- } \\
\text { Barre Syndrome, Encephalopathy, etc }\end{array}$ & 7.43 & 559 & 44 & 17 & 27 & 1 \\
\hline 27 & $\begin{array}{l}\text { Covid-19 and the Nervous System - First Choice Neurology - Dr. } \\
\text { Jeffrey Gelblum }\end{array}$ & 34.20 & 470 & 59 & 50 & 17 & 1 \\
\hline 28 & Covid-19 from Neurological perspective 3 & 5.35 & 451 & 60 & 0 & 11 & 0 \\
\hline 29 & $\begin{array}{l}\text { Coronavirus effects on Brain| COVID19 neurological infection. | } \\
\text { Covid-19 and Neurology }\end{array}$ & 4.43 & 442 & 59 & 24 & 61 & 0 \\
\hline 30 & Neurologist discusses COVID-19 and strokes in some patients & 2.06 & 405 & 47 & 1 & 9 & 0 \\
\hline 31 & Apr 10, 2020 Neurological Problems in "C0 Ved I9 & 3.21 & 398 & 61 & 20 & 37 & 1 \\
\hline 32 & Neurological Implications of COVID-19 with Dr. Joseph Berger & 57.59 & 372 & 21 & 1 & 12 & 1 \\
\hline 33 & $\begin{array}{l}\text { Migraine and COVID-19 - First Choice Neurology - Dr. Jennifer } \\
\text { Buczyne }\end{array}$ & 30.17 & 330 & 78 & 1 & 9 & 1 \\
\hline
\end{tabular}




\begin{tabular}{|c|c|c|c|c|c|c|c|}
\hline $\begin{array}{l}\text { Video } \\
\text { number }\end{array}$ & Video name & $\begin{array}{c}\text { Video } \\
\text { length } \\
\text { (minutes) }\end{array}$ & $\begin{array}{l}\text { View } \\
\text { count }\end{array}$ & $\begin{array}{c}\text { Time } \\
\text { since } \\
\text { video } \\
\text { upload } \\
\text { (days) }\end{array}$ & $\begin{array}{c}\text { Comment } \\
\text { count }\end{array}$ & $\begin{array}{l}\text { Like } \\
\text { count }\end{array}$ & $\begin{array}{l}\text { Dislike } \\
\text { count }\end{array}$ \\
\hline 34 & $\begin{array}{l}\text { The US Government Response to COVID-19 - American } \\
\text { Academy of Neurology }\end{array}$ & 26.43 & 324 & 37 & 0 & 3 & 0 \\
\hline 35 & $\begin{array}{l}\text { Coronavirus in Context: Neurological Effects of COVID-19| } \\
\text { WebMD }\end{array}$ & 17.18 & 346 & 37 & 1 & 12 & 0 \\
\hline 36 & $\begin{array}{l}\text { Epilepsy and COVID-19 - First Choice Neurology - Dr. Andrew } \\
\text { Lerman }\end{array}$ & 29.59 & 293 & 79 & 5 & 6 & 0 \\
\hline 37 & COVID-19 Digest: Neurological Manifestations of COVID-19 & 14.39 & 257 & 49 & 0 & 6 & 1 \\
\hline 38 & $\begin{array}{l}\text { Dr Siddharth Warrier, Neurologist, Wockhardt Hospital, } \\
\text { Mumbai }\end{array}$ & 8.40 & 222 & 55 & 0 & 7 & 0 \\
\hline 39 & $\begin{array}{l}\text { COVID-19 New Symptoms and Signs In Kids | Dr Sailaja Golla, } \\
\text { Pediatric Neurologist | TeluguOne Health }\end{array}$ & 2.56 & 218 & 38 & 0 & 4 & 1 \\
\hline 40 & $\begin{array}{l}\text { How to Manage Headaches During COVID-19 - First Choice } \\
\text { Neurology - Dr. Jeffrey Steinberg }\end{array}$ & 16.09 & 310 & 50 & 1 & 3 & 1 \\
\hline 41 & $\begin{array}{l}\text { Barry J. Byrne, MD, PhD: Adjusting Care for Neuromuscular } \\
\text { Disease Amid COVID-19 }\end{array}$ & 3.36 & 180 & 66 & 0 & 1 & 0 \\
\hline 42 & $\begin{array}{l}\text { Management of Neurological Diseases Amidst the COVID-19 } \\
\text { Pandemic }\end{array}$ & 4.26 & 190 & 20 & 8 & 3 & 0 \\
\hline 43 & Does Covid 19 cause Stroke?? & 25.15 & 176 & 47 & 7 & 4 & 0 \\
\hline 44 & $\begin{array}{l}\text { Jennifer Frontera, MD: Risk of COVID-19 in Patients With } \\
\text { Neurologic Disorders }\end{array}$ & 4.14 & 220 & 41 & 0 & 5 & 0 \\
\hline 45 & Neurology and COVID-19 & 3.38 & 163 & 53 & 2 & 10 & 0 \\
\hline 46 & 2 symptoms warning you to be infected with COVID-19 & 2.48 & 158 & 54 & 1 & 5 & 0 \\
\hline 47 & $\begin{array}{l}\text { CAN CORONAVIRUS AFFECT YOUR BRAIN? Neurological } \\
\text { Symptoms: (COVID-19, 2020) }\end{array}$ & 4.19 & 144 & 28 & 17 & 21 & 1 \\
\hline 48 & $\begin{array}{l}\text { TeleSpecialists 2020: Neurological Effects of COVID-19 } \\
\text { Interview }\end{array}$ & 8.28 & 133 & 50 & 0 & 4 & 0 \\
\hline 49 & $\begin{array}{l}\text { Colorado Boy With Neurological Disease Struggling Without } \\
\text { Physical Therapy During Coronavirus Pandemi }\end{array}$ & 1.58 & 115 & 51 & 0 & 2 & 1 \\
\hline 50 & $\begin{array}{l}\text { Taking Care of Your Neurological Disorder during Coronavirus } \\
\text { (COVID-19) - First Choice Neurology }\end{array}$ & 46.53 & 104 & 84 & 0 & 1 & 0 \\
\hline
\end{tabular}

The mean score of DISCERN was $35.42 \pm 17.53$ (16 to 73), and the mean score of JAMA was $2.02 \pm 1.00$ (1 to 4) according to the first researcher. The mean score of DISCERN was $57.76 \pm 13.71$ ( 31 to 79 ), and the mean score of JAMA was $3.72 \pm 0.73$ ( 1 to 4 ) according to the second researcher. The mean scores of the 2 researchers were $46.59 \pm 10.90$ ( 27.5 to 73.0 ) for DISCERN and $2.87 \pm 0.65$ ( 1 to 4 ) for JAMA There was a high correlation between DISCERN and JAMA scores of the videos $(r=0.667, p<0.001)$.

According to the mean DISCERN scores quality of the videos was found as very poor in $2 \%$, poor in $11 \%$, medium in $46 \%$, good in $18 \%$, and excellent in $12 \%$ (Figure 1 ). The mean JAMA scores of the videos were 2 or low in $6 \%,>2$ to 3 in $70 \%$, and over 3 in 24\% (Figure 2).

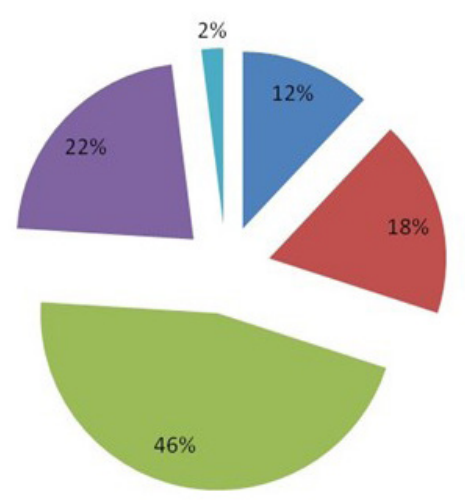

\section{DISCERN score}

- Excellent (63-75)

a $\operatorname{Good}(51-<63)$

average $(39-<51)$

- Poor $(28-<39)$

- Very poor $(<28)$

Fig. 1 Quality of the videos according to the mean DISCERN score of two raters 


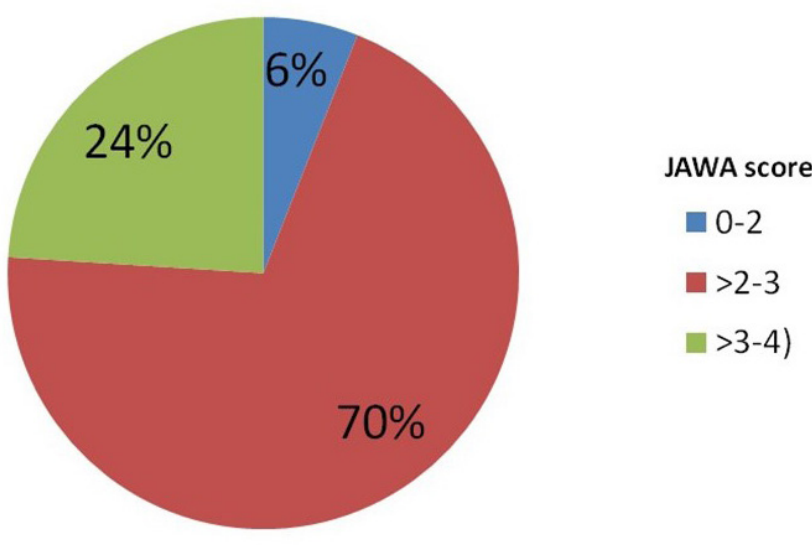

Fig. 2 Quality of the videos according to the mean JAMA score of two raters

The most watched video was a news video about the impacts of the Corona virus on brain, that lasted for 2.27 seconds and was watched approximately 40 thousand times in 55 days. One of the other two videos, which was watched over 10 thousand times in the same airtime, was the health channel video that lasted 1.56 seconds about brain damage due to Corona virus and the news video that lasted 2.23 seconds about less known disease symptoms. While the lower scores of the news videos from both evaluations were remarkable, the JAMA score of 3.5 for the health channel video was above the average.

The average VPI, DISCERN and JAMA scores of the groups formed according to the video sources are presented in Table 4. There was a significant difference detected between DISCERN and JAMA scores of the groups $\left(X^{2}=15.370\right.$, $p=0.002$ and $X^{2}=18.804, p=0.002$, respectively), but not in terms of mean VPI scores ( $\left.X^{2}=3.635, p=0.304\right)$, According to post-hoc analysis, Health Channel mean DISCERN and JAMA scores were significantly higher than News Channel scores $(p=0.001)$

There is no statistically significant correlation between VPI scores and DISCERN or JAMA scores ( $p>0.05)$. There was a weak statistically significant correlation between the video length rate and both the DISCERN scores $(r=0.597$, $p<0.001)$ and JAMA scores $(r=0.585, p<0.001)$. There is no statistically significant correlation between DISCERN or JAMA scores and view count, view rate, comment count, like count, dislike count $(p>0.05)$
TABLE 4: Average VPI, DISCERN and JAMA scores of the videos according to sources

\begin{tabular}{|l|c|c|c|}
\hline \multicolumn{1}{|c|}{ Video source } & VPI & DISCERN & JAMA \\
\hline $\begin{array}{l}\text { HEALTH } \\
\text { CHANNELS }\end{array}$ & $94.78 \pm 6.81$ & $52.36 \pm 11.29$ & $3.10 \pm 0.80$ \\
\hline $\begin{array}{l}\text { NEWS } \\
\text { CHANNELS }\end{array}$ & $94.22 \pm 9.22$ & $38.27 \pm 7.22$ & $2.50 \pm 0.20$ \\
\hline PHYSICIANS & $98.28 \pm 2.87$ & $43.50 \pm 5.47$ & $2.82 \pm 0.40$ \\
\hline PATIENTS & 100 & 44.5 & 2.5 \\
\hline Total & $95.51 \pm 6.93$ & $46.59 \pm 10.90$ & $2.85 \pm 0.72$ \\
\hline
\end{tabular}

\section{DISCUSSION}

In this study, it was examined whether the quality, reliability and validity of the information received from Youtube videos differ in terms of source of the video. The overall quality of videos on YouTube about the neurological symptoms of COVID-19 are low. The quality of the videos from the Health Channels was significantly higher than the ones from the News Channels. The Video Power Index of the videos did not correlate with DISCERN or JAMA scores. The only key feature that was weakly correlated with quality was video length.

Little is known about the neurological symptoms of COVID-19 patients. Systemic inflammation caused by COVID-19 increases the blood brain barrier permeability and allows passage of infected cells and virus to the central nervous system (14). There are few case reports of neurological symptoms in COVID-19 patients, and a study conducted in Wuhan, China reported neurological findings in hospitalized COVID-19 patients (9). Another systematic study conducted in France showed neurologic findings like confusion, encephalopathy, and corticospinal tract in 49 of 58 patients (15).

Headache is a common complaint in COVID-19. The prevalence varies, but it is known to affect one third of patients diagnosed. Nociceptive sensory neurons are affected by cytokines and chemokines formed after neuro inflammation (16-18). In Germany, anosmia was reported in 88.5\% and ageusia in $88.0 \%$ of COVID-19 patients (19). $37 \%$ of patients hospitalized with COVID-19 reported to have impaired consciousness as a result of toxic-metabolic encephalopathy, parenchymal damage, seizures and demyelinating diseases (9). Risk factors that make COVID-19 patients prone to delirium are advanced age, dementia, comorbid diseases and malnutrition (20). Endocrine and metabolic disorders such as hyper/hypoglycemia, hyper/ 
hyponatremia, hyper/hypocalcemia, kidney and liver dysfunction may increase the risk of encephalitis. In addition, cytokine storm can also cause encephalopathy by increasing interleukins 6, 8 and 10 and tumor necrosis factor-alpha (21). Epileptic seizures were observed in only two of 304 patients diagnosed with COVID-19 (22).

In a study, $5 \%$ of hospitalized patients due to COVID-19 in Wuhan reported acute stroke. Of these patients, 11 were hospitalized for ischemic stroke, 1 for cerebral venous sinus thrombosis and 1 for intracerebral hemorrhage (23).

In Italy, 5 GBS patients have been reported subsequently COVID-19 infection, in 4 patients with lower extremity weakness and paresthesia (24). In the electromyography study, two patients had acute inflammatory demyelinating polyneuropathy and three patients had acute motor axonal neuropathy (25). In addition, an acute motor axonal neuropathy patient in Iran and Miller-Fisher variant of GBS in Italy were reported (26).

Resources freely accessible from internet constitute an important resource for the health information needs of the society and such resources are frequently used. However, the validity and reliability of these sources are not under control. To date, many scoring systems have been used to evaluate the quality and accuracy of videos on the internet (27-28). This study is the first study in the literature on information content and reliability of videos published on YouTube about neurological symptoms in COVID-19.

\section{CONCLUSION}

In our study, Youtube videos on neurological symptoms of Covid-19 were evaluated using JAMA and DISCERN scoring systems that are among the most frequently used scoring systems. Videos analyzed showed significant variation according to both scoring systems. The mean DISCERN score of the videos was "average" and JAMA scores were 2.9 over 4.0. These mean values are far from expectations. Considering the distribution of the quality of the videos according to the DISCERN scoring system, only $30 \%$ were scored as 'excellent' or 'good'. Significant proportions of videos have worse than medium scores. It is noteworthy that the values of videos uploaded from health channels in both score systems are higher than other important source news channels.

Youtube is a social media channel that provides rich options and frequently used for visual content. In this respect, it can be said that it meets an important need. It allows rapid sharing on issues affecting the whole world, especially in the COVID epidemic, and is accepted and used by world population. However, the validity and reliability of the content provided in this media is not under control. In the videos examined in our study, this issue has been presented remarkably. There is a need to develop mechanisms for checking the validity of social media shares on issues of general importance such as public health. Until progress is made on this issue, it may be considered to use and include valid content on social media in public health practice.

\section{Ethics Approval}

Ethics committee approval was obtained for the study from XXX University Ethic Committee for Clinical Studies with the decision dated June 09, 2021 and numbered 06-29.

\section{REFERENCES}

1. AlGhamdi KM, Moussa NA. Internet use by the public to search for health-related information. Int J Med Inform. 2012; 81:6. doi:10.1016/j.ijmedinf.2011.12.004

2. Fox S, Duggan M. Health online 2013, 2013. https://www.pewresearch. org/internet/2013/01/15/health-online-2013/. Accessed May 2, 2021.

3. YouTube. YouTube statistic page. https://www.omnicoreagency.com/ youtube-statistics/. Accessed April 25, 2021.

4. Powell J, Inglis N, Ronnie J, et al. The characteristics and motivations of online health information seekers: cross-sectional survey and qualitative interview study. J Med Internet Res. 2011; 13:e20. doi:10.2196/jmir.1600.

5. Atkinson NL, Saperstein SL, Pleis J. Using the internet for healthrelated activities: findings from a national probability sample. $J$ Med Internet Res. 2009; 11:e-4. doi:10.2196/jmir.1035.

6. Bora K, Das D, Barman B, et al. Are Internet videos useful sources of information during global public health emergencies? A case study of YouTube videos during the 2015-16 Zika virus pandemic. Pathog Glob Health. 2018; 112:320-8. doi:10.1080/20477724.2018.150778 4.

7. Velavan TP, Meyer CG. The COVID-19 epidemic. Trop Med Int Health. 2020; 25:278-80. doi:10.1111/tmi.13383.

8. World Health Organization. Situation report Weekly Operational Update on COVID-19, 13 November $2020 . \quad$ https://www.who.int/publications/m/item/ weekly-operational-update-on-covid-19---13-november-2020

9. Wang D, Hu B, Hu C, et al.Clinical characteristics of 138 hospitalized patients with 2019 novel corona virus-infected pneumonia in Wuhan, China. JAMA. 2020; 323:1061-9. doi:10.1001/ jama.2020.1585.

10. Mao L, Jin H,Wang M, et al. Neurologic manifestations of hospitalized patients with corona virus disease 2019 in Wuhan, China. JAMA Neurol. 2020; 77:1-9. doi:10.1001/jamaneurol.2020.1127.

11. Gokcen HB, Gumussuyu G. A quality analysis of disc herniation videos on YouTube. World Neurosurg. 2019; 124:e799-e804. doi:10.1016/j.wneu.2019.01.146. 
12. Charnock D, Shepperd S, Needham G, et al. DISCERN: an instrument for judging the quality of written consumer health information on treatment choices. J Epidemiol Community Health.1999; 53:10511. doi:10.1136/jech.53.2.105.

13. Silberg WM, Lundberg GD, Musacchio RA. Assessing, controlling and assuring the quality of medical information on the Internet: Caveantlector et view or e Let the reader and viewer beware. JAMA. 1997; 277:1244-5. doi:10.1001/jama.1997.03540390074039

14. Kuru T, Eken H. Evaluation of the Quality and Reliability of YouTube Videos on Rotator Cuff Tears. Cureus. 2020; 12(2):e6852. doi:10.7759/cureus.6852.

15. Sankowski R, Mader S, Valdés-Ferrer SI. Systemic inflammation and the brain: novel roles of genetic, molecular, and environmental cues as drivers of neurodegeneration. Front Cell Neurosci. 2015; 9:28. doi:10.3389/fncel.2015.00028.

16. Helms J, Kremer $\mathrm{S}$, Merdji $\mathrm{H}$, et al. Neurologic features in severe SARS-CoV-2 infection. N Engl J Med. 2020; 382:2268-70. doi:10.1056/NEJMc2008597.

17. Jin $\mathrm{X}$, Lian JS, Hu JH, et al. Epidemiological, clinical and virological characteristics of 74 cases of coronavirus-infected disease 2019 (COVID-19) with gastrointestinal symptoms. Gut. 2020; 69(6):10029. doi:10.1136/gutjnl-2020-320926.

18. Borges do Nascimento IJ, Cacic N, Abdulazeem HM, et al. Novel coronavirus infection (COVID-19) in humans: a scoping review and meta-analysis. J Clin Med. 2020; 9(4):E941. doi:10.3390/ jcm9040941.

19. Conti P, D'Ovidio C, Conti C, et al. Progression in migraine: role of mast cells and pro-inflammatory and anti-inflammatory cytokines. Eur J Pharmacol. 2019;844:87-94. doi:10.1016/j.ejphar.2018.12.004.

20. Lechien JR, Chiesa-Estomba CM, De Siati DR, et al. Olfactory and gustatory dysfunctions as a clinical presentation of mildto-moderate forms of the coronavirus disease (COVID-19): a multicenter European study. Eur Arch Otorhinolaryngol. 2020; 277(8):2251-61. doi:10.1007/s00405-020-05965-1.

21. Fat MJL, Doja A, Barrowman N, et al. YouTube videos as a teaching tool and patient resource for infantile spasms. J Child Neurol. 2011; 26:804-9. doi:10.1177/0883073811402345.

22. KrishnanV, Leung LY, Caplan LR. A neurologist's approach to delirium: diagnosis and management of toxic metabolic encephalopathies. Eur J Intern Med. 2014; 25(2):112-6. doi:10.1016/j.ejim.2013.11.010.

23. Lu L, Xiong W, Liu D, et al. New onset acute symptomatic seizure and risk factors in coronavirus disease 2019: a retrospective multicenter study. Epilepsia. 2020; 61(6):e49-e53. doi:10.1111/epi.16524.

24. Li Y, Li M, Wang M, et al. Acute cerebrovascular disease following COVID-19: a single center, retrospective, observational study. Stroke and Vascular Neurology. 2020; 5:3000431. doi:10.1136/ svn-2020-000431.

25. Toscano G, Palmerini F, Ravaglia S, et al. Guillain-Barré syndrome associated with SARS-CoV-2. N Engl J Med. 2020; 382:2574-6. doi:10.1056/NEJMc2009191.

26. Sedaghat Z, Karimi N. Guillain Barre syndrome associated with COVID-19 infection: a case report. J Clin Neurosci. 2020; 76:233-5. doi:10.1016/j.jocn.2020.04.062.

27. Gutiérrez-Ortiz C, Méndez A, Rodrigo-Rey S, et al. Miller Fisher syndrome and polyneuritis cranialis in COVID-19. Neurology. 2020; 95(5):e601-5. doi:10.1212/WNL.0000000000009619.

28. Ahmed S, Leurent B, Sampson EL. Risk factors for incident delirium among older people in acute hospital medical units: a systematic review and meta-analysis. Age Ageing. 2014; 43(3):326-33. doi:10.1093/ageing/afu022.

29. Haymes AT, Harries V. 'How to stop a nose bleed': an assessment of the quality of epistaxis treatment advice on YouTube. J Laryngol Otol. 2016; 130:749-54. doi:10.1017/S0022215116008410. 